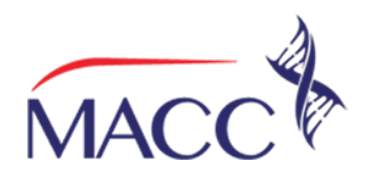

\title{
Hubungan Kejadian Tromboembolisme Vaskular Terhadap Mortalitas COVID-19: Sebuah Studi Literatur
}

\author{
Raihanah Anwar ${ }^{1 *}$, Fitri Agustina Huspa ${ }^{2}$, Dewi Yulianti Bisri ${ }^{3}$
}

1. Program Studi Pendidikan Dokter, Fakultas Kedokteran, Universitas Padjadjaran, Sumedang

2. Departemen IImu Kedokteran Forensik dan Medikolegal, Fakultas Kedokteran, Universitas Padjadjaran - RSUP Dr. Hasan Sadikin, Bandung

3. Departemen Anestesiologi dan Terapi Intensif, Fakultas Kedokteran, Universitas Padjadjaran - RSUP Dr. Hasan Sadikin, Bandung

\begin{abstract}
ABSTRAK
Latar Belakang: COVID-19, infeksi virus akibat SARS-CoV-2, menampilkan berbagai gambaran klinis dari gejala asimtomatik hingga kematian. Respons inflamasi pada COVID-19 menyebabkan fase hiperkoagulasi dan mengakibatkan lebih dari $25 \%$ kejadian tromboembolisme pada pasien rawat inap COVID-19. Pada tromboembolisme, terjadi elevasi level D-dimer, hal ini berasosiasi dengan perburukan prognosis dan mortalitas pasien COVID-19. Penelitian ini bertujuan untuk mengevaluasi penelitian yang menganalisis hubungan kejadian tromboembolisme pada COVID-19 dan mortalitas. Diharapkan penelitian ini dapat menjadi dasar bagi para klinisi untuk mengevaluasi penatalaksanaan COVID-19.

Metode: Penelitian menggunakan pendekatan studi literatur dengan kata kunci "Thromboembolism" atau "Venous Thromboembolism", "COVID-19", "SARS-CoV-2" atau "Coronavirus Disease 2019", dan "Mortality" melalui database PubMed dan disaring berdasarkan kriteria yang telah ditetapkan.

Hasil: Dari 4 artikel yang sesuai dengan kriteria inklusi, dua artikel menyatakan adanya hubungan kejadian tromboembolisme dengan kematian pada pasien COVID-19 dan dua artikel menyatakan tidak ada hubungan. Untuk mengklarifikasi dua pernyataan yang kontradiktif tersebut, peneliti mencari lebih dalam penelitian yang mendukung.

Simpulan: Keempat artikel yang dianalisis melaporkan tingginya kejadian tromboembolisme pada pasien COVID-19. Dua di antaranya menyatakan asosiasi antara tromboembolisme dan kematian pada COVID-19 dan sisanya menyatakan tidak ada asosisasi. Namun, pertanyaan penelitian untuk mengetahui hubungan kejadian tromboembolisme pada COVID-19 dengan kematian masih belum dapat diketahui.
\end{abstract}

Kata Kunci: COVID-19, Tromboembolisme, Tromboembolisme Vena, Mortalitas, D-dimer 


\title{
The Association of Thromboembolism in COVID-19 with Mortality: a Literature Review
}

\author{
Raihanah Anwar ${ }^{1}$, Fitri Agustina Huspa², Dewi Yulianti Bisri ${ }^{3^{*}}$
}

1. Program Studi Pendidikan Dokter, Fakultas Kedokteran, Universitas Padjadjaran, Sumedang

2. Departemen IImu Kedokteran Forensik dan Medikolegal, Fakultas Kedokteran, Universitas Padjadjaran - RSUP Dr. Hasan Sadikin, Bandung

3. Departemen Anestesiologi dan Terapi Intensif, Fakultas Kedokteran, Universitas Padjadjaran - RSUP Dr. Hasan Sadikin, Bandung

*corresponding author

\begin{abstract}
Background: COVID-19, a viral infection due to SARS-CoV-2, displays broad clinical symptoms ranging from asymptomatic to death. The inflammatory response in COVID-19 activating hypercoagulable state, resulting in increased thromboembolic events as over $25 \%$ in in-hospital patients. Thromboembolic events in COVID-19 associated with elevated D-dimer levels and thus associated with poor prognosis and mortality. This study aims to derive evidence of the relationship between thromboembolism in COVID-19 and mortality.

Methods: The study uses a literature review approach, using keywords of "Thromboembolism" or "Venous Thromboembolism", "COVID-19", "SARS-CoV-2" or "Coronavirus Disease 2019", and "Mortality" through the PubMed database and selected based on the criteria that have been set. Results: Of the four articles that match the inclusion criteria, two articles stated a relationship between thromboembolism and mortality in COVID-19 patients and two articles that stated there was no relationship. To clarify these two contradictory statements, the researcher looks deeper into supporting research.

Conclusion: The four articles that reported the incidence of thromboembolism in COVID-19 patients, two of which stated a relationship between thromboembolism and death in COVID-19, and the rest stated that there was no association. However, the research question remains unresolved for the association between thromboembolic events in COVID-19 and mortality.
\end{abstract}

Keywords: COVID-19, Thromboembolism, Venous Thromboembolism, Mortality, D-dimer 


\section{PENDAHULUAN}

Coronavirus Disease 2019 (COVID-19) adalah infeksi virus yang mudah menular dan patogenik yang disebabkan oleh severe acute respiratory syndrome coronavirus 2 (SARSCoV-2). Penyakit ini pertama kali muncul di Wuhan, Cina sejak Desember 2019 dan dengan cepat menyebar ke seluruh dunia menjadi pandemi. Organisasi Kesehatan Dunia (World Health OrganizationWHO) mencatat adanya 2 juta kematian di dunia dan 25.767 kematian di Indonesia hingga 17 Januari 2021. ${ }^{1}$ COVID-19 menampilkan berbagai gambaran klinis mulai dari gejala asimtomatik, penyakit saluran pernapasan atas ringan, pneumonia berat, atau bahkan kematian. $^{2}$

Penelitian melaporkan adanya respons inflamasi pada COVID-19 yang mengaktifkan keadaan hiperkoagulasi3 dan mengakibatkan peningkatan kejadian tromboembolisme sebanyak lebih dari $25 \%$ pada pasien COVID-19 yang dirawat inap. ${ }^{3,4}$ Tromboembolisme diketahui sebagai salah satu komplikasi dari infeksi virus.

SARS-CoV-2 yang berikatan dengan reseptor angiotensin-converting enzyme 2 (ACE-2) mengakibatkan terjadinya aktivasi endotel dan peningkatan mediator inflamasi. ${ }^{4}$ Sitokin inflamasi kemudian menyebabkan kerusakan endotel dan peningkatan faktor koagulasi (tissue factor/TF). Bersamaan dengan trombosit dan leukosit, aktivasi sel endotel menginisiasi proses koagulasi melalui TF dan menyebabkan keadaan hiperkoagulasi. ${ }^{5}$

Penelitian terbaru menyatakan kejadian tromboembolisme pada COVID-19 menyebabkan elevasi level D-dimer, hal ini berasosiasi dengan perburukan prognosis dan mortalitas pasien COVID-19.6 Beberapa penelitian telah menyelidiki hubungan antara tromboembolisme pada COVID-19 dan kematian. ${ }^{7}$ Studi literatur ini dilakukan untuk mengevaluasi penelitian yang menganalisis hubungan kejadian tromboembolisme pada COVID-19. Diharapkan, penelitian ini dapat menjadi dasar bagi para klinisi untuk mengevaluasi tatalaksana COVID-19.

\section{METODE}

\section{Strategi Pencarian dan Kriteria Seleksi}

Peneliti melakukan pencarian literatur dari database elektronik berupa National Library of Medicine (PubMed), Google Scholar, Clinicalkey, CINAHL, dan PLOS untuk artikel yang menganalisis kejadian tromboembolisme pada COVID-19. Kata kunci yang digunakan untuk mengidentifikasi penelitian adalah "Thromboembolism" atau "Venous Thromboembolism", "COVID-19", "SARS-CoV-2" atau "Coronavirus Disease 2019", dan "Mortality". Pencarian literatur dilakukan pada tanggal Juni 2020 hingga 14 Januari 2021, tanpa batasan filter bahasa dan tahun publikasi. Peneliti menyaring dari judul dan abstrak untuk memastikan kesesuaian literatur dan kemudian artikel dibaca lebih lanjut untuk mendapatkan hasil yang relevan.

Kriteria inklusi pada sampel penelitian ini berupa artikel yang melaporkan kematian akibat kejadian tromboembolisme pada pasien COVID-19 dan mempunyai tujuan untuk menganalisis hubungan tersebut, menggunakan Bahasa Inggris, menggunakan data primer dalam penelitiannya dan teks lengkap penelitian dapat ditinjau. Artikel yang dieksklusi pada penelitian ini adalah artikel dengan jenis publikasi lain (laporan kasus, artikel review, atau editorial), hanya tersedia berbentuk abstrak, dan berbahasa selain Bahasa Inggris.

\section{Ekstraksi data dan Penilaian Kualitatif}

Ekstraksi data dari literatur meliputi karakteristik umum penelitian, karakteristik populasi COVID-19 dengan kejadian tromboembolisme, dan temuan utama penelitian. Karakteristik umum penelitian yang diekstraksi yaitu penulis pertama, tahun publikasi, desain penelitian, lokasi, dan jumlah keseluruhan sampel penelitian. Karakteristik pasien COVID-19 dengan tromboembolisme yang diambil berupa jumlah sampel, usia dalam median, jenis kelamin laki-laki dan komorbiditas. Untuk mengevaluasi validitas tiap artikel, kualitas metodologi dilakukan dengan penilaian menggunakan Critical Appraisal Skills Programme (CASP) yang terdiri dari dua belas pertanyaan sesuai desain studi penelitian.

\section{HASIL DAN DISKUSI}

Pencarian awal menghasilkan 424 artikel (PubMed n=424, Google Scholar n=0, ClinicalKey 
$\mathrm{n}=0$, CINAHL $\mathrm{n}=0$, dan PLOS $\mathrm{n}=0$ ). Sebanyak 246 duplikat dihapus dan tersisa 178 artikel yang kemudian disaring. Dari 178 artikel, 161 artikel tidak relevan dengan topik penelitian dan menyisakan 17 teks lengkap artikel untuk dibaca. Sebanyak 13 dari 17 artikel dikeluarkan dengan alasan seperti hanya terdapat abstrak, merupakan artikel review, dan artikel yang tidak memberikan data tentang asosiasi kejadian tromboembolisme pada COVID-19 dan kematian. Dari proses ini, ditemukan 4 literatur yang sesuai dengan kriteria inklusi. Diagram PRISMA pada

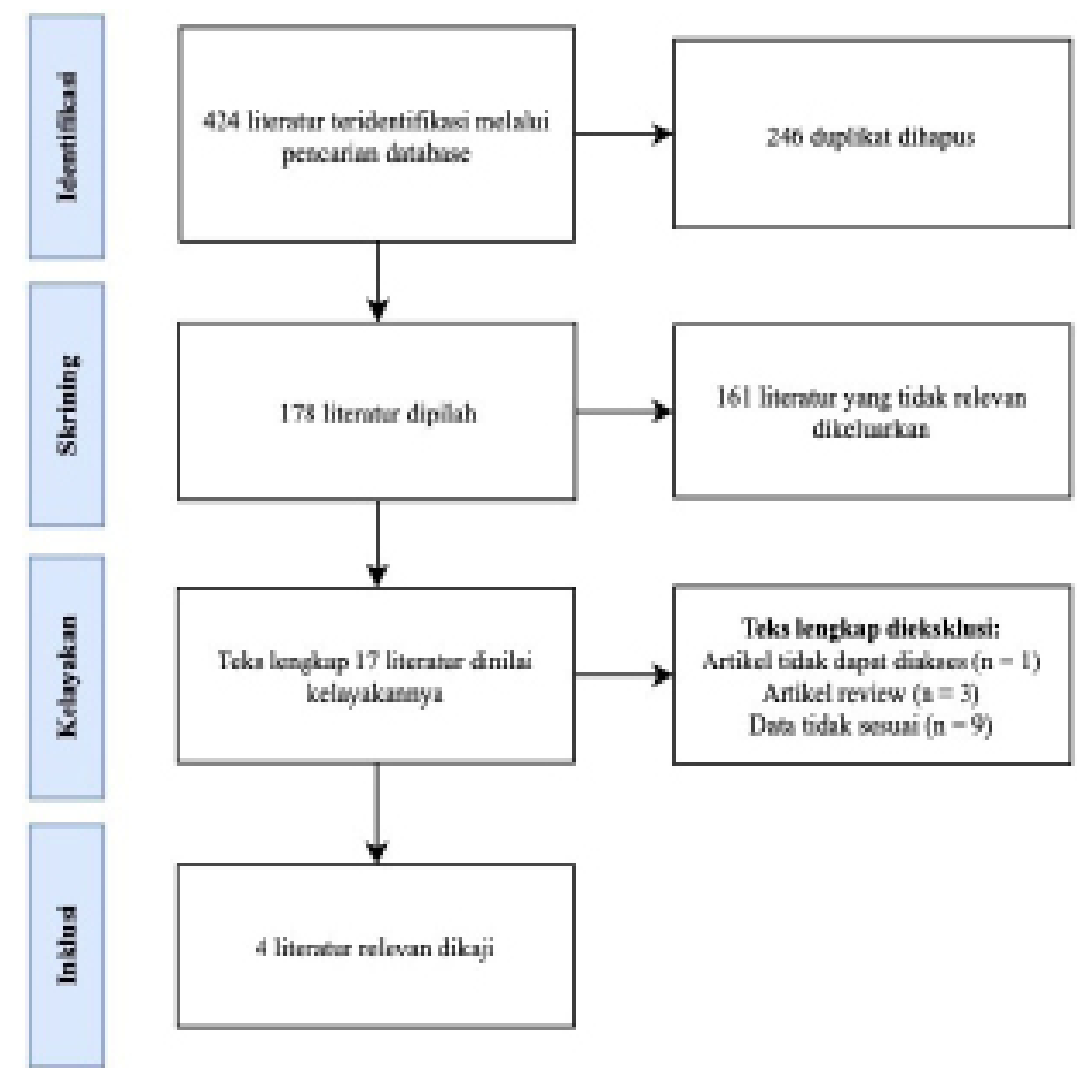

Gambar 1. Proses Seleksi Literatur

Gambar 1 di bawah menunjukkan alur seleksi literatur yang dilakukan.

Dari 4 artikel yang memenuhi kriteria inklusi, terdapat 2 studi kohort prospektif, 1 studi kohort retrospektif, dan 1 studi cross-sectional. Satu dari empat artikel mengevaluasi temuan klinis postmortem; dan tiga artikel lain meneliti antemortem..$^{8-11}$ Karakteristik tiap artikel tercantum dalam Tabel 1.

\section{Demografi Pasien COVID-19 dengan Kejadian Tromboembolisme}

Karakteristik demografi sampel dalam penelitian ini tercantum dalam Tabel 1. Usia tua dan jenis kelamin laki-laki tampaknya menjadi temuan umum dalam COVID-198-11 dan menjadi faktor risiko penting dalam kematian COVID-19. Analisis multivariabel oleh Chang et al. melaporkan bahwa secara independen jenis kelamin lakilaki berhubungan dengan DVT. Sementara itu, analisis univariat menunjukkan usia dan lama berbaring di tempat tidur (bedridden time) dikaitkan dengan DVT. ${ }^{10}$ Pada pasien yang berusia lebih dari 60 tahun, banyak faktor yang dapat meningkatkan mortalitas, seperti adanya komorbiditas, lebih lama berbaring di tempat tidur, respons imun yang lebih lemah, penurunan fungsi organ, dan penyakit inflamasi kronis. Karena peradangan yang konstan, pada usia yang lebih tua mengalami pengeluaran sel $T$ yang tidak optimal secara persisten akibat penurunan kemampuan respon imun. ${ }^{12}$ 
Tabel 1. Karakteristik Literatur

\begin{tabular}{|c|c|c|c|c|c|c|c|c|c|c|}
\hline \multirow{2}{*}{$\begin{array}{l}\text { Penulis } \\
\text { (Tahun terbit) }\end{array}$} & \multirow{2}{*}{$\begin{array}{l}\text { Desain } \\
\text { Studi }\end{array}$} & \multirow{2}{*}{$\begin{array}{l}\text { Kota } \\
\text { (Negara) }\end{array}$} & \multirow{2}{*}{$\begin{array}{l}\text { Populasi } \\
\text { yang } \\
\text { Diteliti }\end{array}$} & \multirow{2}{*}{$\mathrm{N}$} & \multicolumn{4}{|c|}{ Pasien COVID-19 dengan Kejadian Tromboembolisme } & \multirow{2}{*}{$\begin{array}{l}\text { Jumlah } \\
\text { Kematian } \\
(\%)\end{array}$} & \multirow{2}{*}{ Temuan Utama } \\
\hline & & & & & N (\%) & $\begin{array}{l}\text { Umur } \\
\text { (median, } \\
\text { tahun) }\end{array}$ & $\begin{array}{l}\text { Pria } \\
(\%)\end{array}$ & Komorbiditas & & \\
\hline $\begin{array}{l}\text { Zhang et al } \\
\text { (2020) }\end{array}$ & $\begin{array}{l}\text { Cross- } \\
\text { sectional }\end{array}$ & $\begin{array}{l}\text { Wuhan } \\
\text { (Cina) }\end{array}$ & Non-ICU & 143 & 66 [46.1\%] & $67^{*}$ & 54.5 & $\begin{array}{l}\text { HTN [42.4\%] } \\
\text { DM [19.7\%] } \\
\text { CAD [13.6\%] } \\
\text { Keganasan [4.5\%] } \\
\text { Penyakit Liver Kronis } \\
\text { [1.5\%] } \\
\text { CKD [1.5\%] }\end{array}$ & 35 & $\begin{array}{l}\text { Pasien dengan DVT secara signifikan } \\
\text { mengalami perburukan dibandingkan } \\
\text { mereka yang tidak mengalami DVT, } \\
\text { termasuk kematian dan tingkat } \\
\text { kelangsungan hidup yang lebih rendah } \\
\text { di antara pasien COVID-19 yang } \\
\text { dirawat di rumah sakit. }\end{array}$ \\
\hline $\begin{array}{l}\text { Wichmann et } \\
\text { al (2020) }\end{array}$ & $\begin{array}{l}\text { Kohort } \\
\text { prospektif }\end{array}$ & $\begin{array}{l}\text { Hamburg } \\
\text { (Jerman) }\end{array}$ & Mortuary & 12 & $7[58 \%]$ & 73 & 75 & $\begin{array}{l}\text { Obesitas [25\%] } \\
\text { CHD [50\%] } \\
\text { Asma atau COPD [25\%] } \\
\text { penyakit Arteri Perifer } \\
{[25 \%]} \\
\text { DM [25\%] } \\
\text { Penyakit Neurodegeneratif } \\
{[25 \%]} \\
\text { CKD [17\%] } \\
\text { A.fib }[17 \%]\end{array}$ & 12 & $\begin{array}{l}\text { Emboli paru dinyatakan sebagai } \\
\text { penyebab langsung kematian pada } \\
33 \% \text { pasien. }\end{array}$ \\
\hline $\begin{array}{l}\text { Chang et al } \\
(2020)\end{array}$ & $\begin{array}{l}\text { Kohort } \\
\text { retrospektif }\end{array}$ & $\begin{array}{l}\text { New York } \\
\text { (AS) }\end{array}$ & $\begin{array}{l}\text { ICU } \\
\text { Non-ICU }\end{array}$ & 443 & $58[31 \%]$ & 62 & 76 & $\begin{array}{l}\text { HTN [57\%] HLD [47\%] DM } \\
\text { [29\%] CAD [9\%] COPD [9\%] } \\
\text { Keganasan [9\%] CHF [2\%] } \\
\text { A.fib [2\%] Hiperkoagulasi } \\
\text { [2\%] }\end{array}$ & 19 & $\begin{array}{l}\text { Tidak ada hubungan yang ditemukan } \\
\text { antara DVT pada COVID-19 dan } \\
\text { kematian di rumah sakit. }\end{array}$ \\
\hline $\begin{array}{l}\text { Kapoor et al } \\
(2020)\end{array}$ & $\begin{array}{l}\text { Kohort } \\
\text { prospektif }\end{array}$ & $\begin{array}{l}\text { New York } \\
\text { (AS) }\end{array}$ & $\mathrm{ICU}$ & 107 & $40[37 \%]$ & $64.3^{*}$ & 50 & $\begin{array}{l}\text { DM [42.5\%] HTN [70.2\%] } \\
\text { CKD [15\%] ERSD [2.5\%] } \\
\text { CAD [10\%] CHF [5\%] } \\
\text { A.fib [2.5\%] COPD [10\%] } \\
\text { Keganasan [7.5\%] Cirrhosis } \\
\text { [2.5\%] }\end{array}$ & NA & $\begin{array}{l}\text { Kejadian tromboembolisme tidak } \\
\text { berhubungan dengan risiko kematian } \\
\text { yang lebih tinggi di antara pasien } \\
\text { COVID-19 di ICU. }\end{array}$ \\
\hline
\end{tabular}

Data dipresentasikan dalam $\mathrm{N}(\%)$, dengan $\mathrm{N}=$ ukuran sampel.

* Studi tidak melaporkan median, hasil direpresentasikan dalam mean.

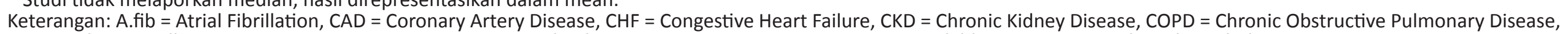
$\mathrm{DM}=$ Diabetes Mellitus, ICU = Intensive Care Unit, HLD = Hyperlipidemia, HTN = Hypertension, NA = Not available, VTE = Venous Thromboembolism. 


\section{Karakteristik VTE pada COVID-19}

Beberapa penelitian melaporkan insidensi VTE pada pasien COVID-19. Dari empat artikel yang dianalisis, VTE pada COVID-19 lebih banyak terjadi pada ekstremitas bawah. Zhang et al. melaporkan $65.2 \%$ pasien DVT mengalami trombosis pada vena distal dan $34.8 \%$ vena proksimal (vena popliteal atau lebih proksimal). ${ }^{10}$ Di samping itu, penelitian oleh Chang et al. melaporkan pada pasien terjadi DVT $20 \%$ terjadi di ekstremitas bawah dan $7 \%$ terjadi di ekstremitas atas. DVT ekstremitas bawah pada pasien ini tersebar pada $63 \%$ vena distal (vena soleal, tibialis, gastrocnemius); $15 \%$ bilateral; $13 \%$ vena proksimal (vena iliac, femoralis, popliteal). ${ }^{11}$ Kapoor et al menyatakan bahwa dari 52 pasien dengan kejadian tromboembolisme, 21 di antaranya terjadi pada ekstremitas bawah dan 9 pada ekstremitas atas. Adapun stroke iskemik akut terjadi pada 4 pasien. ${ }^{8}$ Autopsi oleh Wichmann et al. menunjukkan dari sepertiga kasus emboli paru, trombus tersebut berasal dari vena dalam ekstremitas bawah. Ditemukan trombus pada kedua ekstremitas bawah semua pasien dengan DVT, dan trombus pada vena prostat pada duapertiga pasien pria..$^{9}$

\section{Koagulopati Otak pada Pasien COVID-19}

SARS-CoV-2 mempunyai protein spike (S) sehingga dapat berikatan dengan ACE-2 yang terdapat endotel dan otot polos arteri di otak. Inflamasi pada endotel mengakibatan teraktivasinya fase koagulasi berkontribusi dalam terbentuknya trombosis, termasuk stroke, dengan COVID-19 sebagai pemicu. Virus ini masuk ke otak melalui peredaran darah otak dengan adanya inflamasi sistemik ataupun dengan penyebaran melalui sistem transpor aksonal retrograde melalui bulbus olfaktorius. Infeksi pada nervus sensorik bulbus olfaktorius menyebabkan pasien mengalami anosmia. Pelepaskan sitokin seperti interleukin (IL) dan tumor necrosis factor (TNF) secara masif oleh makrofag membantu ekspresi TF. TF mengaktivasi jalur koagulasi ekstrinsik dan menyebabkan deposit fibrin dan membentuk gumpalan darah, meningkatkan risiko stroke iskemik akut. ${ }^{13}$ Di sisi lain, infeksi virus yang tidak terkontrol dan terus menerus mengakibatkan pelepasan sitokin yang berlebihan atau 'cytokine storm' dan merusak pertahanan dan meningkatkan permeabilitas sawar darah otak, menyebabkan stroke hemoragik. SARS-CoV-2 menurunkan ekspresi ACE-2 dan meningkatkan pembentukan angiotensin-II (Ang2) sebagai vasokonstriktor pada arteri serebral, meningkatkan tekanan darah dan risiko stroke hemoragik. ${ }^{13}$

Pada COVID-19 terjadi hipoksemia akibat gangguan pernapasan, disfungsi endotel pada jantung pun sistemik, dan viral miokarditis menimbulkan kerusakan miokardium. Hal ini dapat menyebabkan aritmia akibat aktivasi sistem saraf simpatis, pembentukan trombus intrakardia, dan meningkatkan risiko stroke kardioemboli. Hiperkoagulasi dapat menimbulkan kejadian tromboembolisme dan mengakibatkan stroke iskemik akibat kardioemboli atau emboli paradoks. Dengan demikian, oklusi vaskular yang mengarah pada stroke dapat terjadi pada usia muda dan tanpa faktor risiko. ${ }^{14}$ Hipoksia akibat SARSCoV-2 dapat mengganggu sawar darah otak, menimbulkan stroke iskemik, kematian sel otak, aterosklerosis, perdarahan, edema otak, dan vaskular demensia. ${ }^{15}$ Penelitian oleh Yamakawa et al. menunjukkan bahwa diantara pasien dengan stroke, tipe stroke iskemik lebih sering terjadi (96.6\%) dengan gejala yang umum terjadi seperti adanya hemiparesis (65.7\%), perubahan tingkat kesadaran (51.4\%), dan disartia (34.3\%) juga mengalami peningkatan level D-dimer dan CRP. Frekuensi pasien COVID-19 dengan stroke pada penelitian ini sebesar $1.1 \%$ dengan tingkat kematian sebesar $44.2 \%$ akibat adanya penghentian perawatan medis saat prognosis memburuk, adanya kerusakan multi-organ, dan koagulopati sistemik. Populasi pasien berisiko stroke adalah berusia tua, jenis kelamin pria, dan mempunyai komorbiditas seperti hipertensi, dislipidemia, dan diabetes. ${ }^{16}$

\section{Temuan Abnormal Hasil Laboratorium pada pasien COVID-19 dengan Kejadian Tromboembolisme}

Studi antemortem melaporkan temuan laboratorium abnormal pada pasien dengan kejadian tromboembolisme yang lebih tinggi seperti C-reactive protein (CRP), peak D-dimer, dan nilai prothrombin time..$^{8,10,11}$ Tingginya temuan tersebut pun dikaitkan dengan DVT.10 CRP sebagai reaktan yang diproduksi oleh hati pada fase akut, meningkat saat reaksi inflamasi. 
Lippi et al. melaporkan terdapat peningkatan nilai CRP (75-93\% kasus) dan nilai D-dimer (36$43 \%$ kasus). ${ }^{17}$ Dengan aktivasi endotel melalui reseptor ACE-2 yang merupakan reseptor fungsional SARS-CoV-2, terjadi gangguan hemostatik pada pasien COVID-19. Oleh sebab itu, acapkali dilaporkan adanya peningkatan D-dimer sebagai salah satu temuan dominan pada COVID-19. Dibandingkan dengan pasien tanpa kejadian tromboembolisme, nilai peak D-dimer pada pasien dengan kejadian tromboembolisme dinyatakan lebih tinggi. ${ }^{8,11}$

Pengukuran D-dimer sering digunakan untuk skrining awal pasien yang dicurigai mengalami VTE, karena D-dimer merupakan penanda adanya proses fibrinolisis endogen. Trombosis dan aktivitas fibrinolitik, peradangan, dan infeksi adalah beberapa alasan paling umum terhadap terjadinya peningkatan D-dimer. Pada COVID-19, peningkatan D-dimer pun sering terjadi. Zhang et al. menganalisis bahwa D-dimer sendiri memiliki sensitivitas $88,5 \%$ dan spesifisitas $52,8 \%$ untuk akurasi diagnostik, meskipun penelitian tersebut mempunyai limitasi yaitu tidak adanya kelompok kontrol, juga keterbatasan waktu dan sumber daya medis. ${ }^{10}$ Menurut penelitian terbaru, D-dimer diketahui berhubungan dengan mortalitas pasien rawat inap, ${ }^{11}$ dengan tambahan studi postmortem menunjukkan peningkatan D-dimer pada 4 dari 10 pasien. $^{9}$ Penemuan ini menunjukkan bahwa uji D-dimer dapat digunakan dalam memprediksi perjalanan klinis dan luaran penyakit COVID-1912. Selain itu, peningkatan persisten D-dimer setelah diberikan antikoagulan dilaporkan berhubungan dengan mortalitas di rumah sakit ${ }^{11}$ dan kemungkinan berhubungan dengan proses terjadinya VTE. Dengan demikian, nilai D-dimer dapat digunakan untuk mengidentifikasi pasien berisiko tinggi.

\section{Hubungan Kejadian Tromboembolisme pada COVID-19 dan Mortalitas}

Melalui Kaplan-Meier survival curves, Zhang et al. menyatakan bahwa pasien dengan DVT secara signifikan mengalami perburukan hasil klinis yang lebih tinggi, termasuk kematian $(34,8 \%$ vs $11,7 \%)$, dibandingkan mereka yang tidak mengalami DVT. Namun, perlu diperhatikan adanya limitasi seperti kurangnya sumber daya medis, tidak adanya kelompok kontrol, dan jumlah pemeriksaan penunjang yang rendah pada penelitian ini. ${ }^{10}$ Untuk mendukung pernyataan ini, meta-analisis oleh Malas et al., menyatakan jika dibandingkan dengan pasien tanpa kejadian tromboembolisme, COVID-19 dan tromboembolisme berhubungan dengan peningkatan sebesar $74 \%$ terhadap kematian. ${ }^{7}$ Karena risiko kematian ini tidak dapat disangkal, tromboprofilaksis dapat diberikan kepada pasien COVID-19 sesuai dengan profil risiko untuk mencegah hasil yang tidak diinginkan.

Otopsi yang dilakukan oleh Wichmann et al., menemukan bahwa sepertiga pasien dengan COVID-19 yang meninggal mengalami emboli paru sebagai penyebab kematian langsung. Namun demikian, ukuran sampel yang kecil mungkin memperbesar estimasi kejadian emboli paru pada studi ini. Pemeriksaan histopatologi menunjukkan kerusakan alveolar terdifusi (diffuse alveolar damage) pada $67 \%$ pasien. Mikrotrombus terlihat dalam arteri kecil paruparu dan prostat, tetapi tidak di organ lain, dan tromboembolisme ditemukan pada 5 dari 12 pasien. ${ }^{9}$ Otopsiterbarumelaporkantrombusarteri pulmonalis tanpa adanya tromboembolisme, menunjukkan bahwa daripada sebagai hasil embolisasi, trombus pada paru terbentuk secara in situ di arteri pulmonalis. ${ }^{18,19}$ Ditemukan pula trombosis makrovaskular dan mikrovaskular pada multiorgan pada pasien, terlepas dari level antikoagulan pasien. Namun, hal ini mungkin terjadi karena timbulnya emboli yang lebih kecil yang menempel pada dinding pembuluh darah, sehingga trombus besar terbentuk dengan cepat. ${ }^{19}$ Temuan lain terkait kondisi kronis yang sebelumnya ada pada pasien, seperti hipertrofi atau jaringan parut pada miokardium. Beragam pola infiltrasi retikuler dan infiltrat yang parah, padat, dan terkonsolidasi di kedua paru terlihat pada Postmortem Computed Tomography (PMCT). Sejalan dengan itu, antemortem dan postmortem CT menunjukkan bilateral ground glass opacity (GGO) di kedua lobus bawah dan chest tube. Temuan ini diduga dapat berkontribusi pada kegagalan pernapasan pada pasien COVID-19 kritis dengan pneumonia, karena emboli paru berhubungan dengan kegagalan resusitasi pada 3 dari 4 pasien. ${ }^{9}$

Analisis regresi logistik yang dilakukan oleh Chang et al., menemukan bahwa DVT tidak 
berhubungan dengan kematian di rumah sakit, dengan tingkat kejadian DVT sebesar 2-13\%. Pada Mei 2020, artikel ini merupakan studi paling luas yang mengevaluasi karakteristik dan kejadian DVT dengan pasien COVID-19 yang diperiksa USG dupleks. ${ }^{11}$ Namun, penelitian mempunyai limitasi yaitu jumlah pasien yang menjalani ultrasonografi dupleks untuk mendiagnosis DVT dibatasi dalam penelitian sebagai upaya menurunkan risiko penularan infeksi dan adanya ketidakstabilan kondisi pasien. Sebaliknya, penelitian lain menemukan bahwa VTE merupakan penyebab mortalitas yang signifikan pada COVID-19.20 Terakhir, Kapoor et al. menemukan bahwa kejadian tromboembolisme pada pasien COVID-19 di ICU tidak berhubungan dengan peningkatan risiko kematian. Dibandingkan dengan pasien tanpa tromboembolisme, tidak ditemukan peningkatan risiko dan tidak ada perbedaan yang signifikan nilai puncak penanda inflamasi pada kedua kelompok. Namun, pelaksanaan pemeriksaan penunjang pada penelitian ini, seperti CT, masih terbatas. ${ }^{8}$ Penelitian di Belanda yang mengevaluasi komplikasi trombotik pada pasien COVID-19 yang dirawat di ICU, menunjukkan bahwa pasien dengan komplikasi trombotik berada di risiko yang lebih tinggi dari semua penyebab kematian meskipun diberikan tromboprofilaksis. ${ }^{18}$ Dengan pernyataan ini, VTE perlu diperiksa pada pasien COVID-19 bahkan pada pasien dengan tromboprofilaksis.

Peneliti mengalami beberapa keterbatasan dalam penelitian ini. Pertama, jumlah artikel yang dianalisis terlalu sedikit untuk mengevaluasi hubungan kejadian tromboembolisme pada COVID-19 dan kematian. Selain itu, kasus COVID-19 baru terjadi selama satu tahun dan jumlah penelitian yang menganalisis penyakit COVID-19 masih terbatas.

Jumlah sampel yang kecil dalam artikel yang dianalisis pada penelitian ini dan adanya penelitian yang mendiagnosis kejadian tromboembolisme hanya berdasarkan gejala, dapat menyebabkan bias pada tingkat kejadian tromboembolisme pada pasien dengan COVID-19. Hal ini dapat memengaruhi estimasi jumlah kasus yang terlalu rendah atau terlalu tinggi dari seharusnya dan juga memengaruhi hasil analisis yang dilakukan.

\section{KESIMPULAN}

Peneliti menemukan 2 literatur yang menyatakan kejadian tromboembolisme berhubungan dengan kematian pada pasien COVID-19 dan 2 literatur yang menyatakan tidak ada hubungan. Untuk mengklarifikasi dua pernyataan yang kontradiktif, peneliti mencari artikel yang dapat mendukung penyataan tersebut. Meskipun dalam keempat artikel melaporkan kejadian tromboembolisme yang tinggi pada pasien rawat inap COVID-19, pertanyaan penelitian untuk mengetahui hubungan kejadian tromboembolisme pada COVID-19 dengan kematian masih belum dapat diketahui.

\section{DAFTAR PUSTAKA}

1. WHO Coronavirus Disease (COVID-19) Dashboard I WHO Coronavirus Disease (COVID-19) Dashboard [Internet]. [cited 2021 Jan 18]. Available from: https:// covid19.who.int/

2. Huang $C$, Wang $Y$, Li X, Ren L, Zhao J, Hu Y, et al. Clinical features of patients infected with 2019 novel coronavirus in Wuhan, China. Lancet. 2020;395(10223):497-506.

3. Wright FL, Vogler TO, Moore EE, Moore HB, Wohlauer M V, Urban S, et al. Fibrinolysis Shutdown Correlation with Thromboembolic Events in Severe COVID-19 Infection. J Am Coll Surg [Internet]. 2020 Aug [cited 2021 Jan 18];231(2):193-203.e1.

4. Breakey N, Escher R. D-dimer and mortality in COVID-19: a self-fulfilling prophecy or a pathophysiological clue? Swiss Med Wkly [Internet]. 2020 May 18 [cited 2020 Aug 10];150(2122):w20293.

5. Branchford BR, Carpenter SL. The Role of Inflammation in Venous Thromboembolism. Front Pediatr [Internet]. 2018 May 23 [cited 2020 Aug 8];6:142.

6. Zhou F, Yu T, Du R, Fan G, Liu Y, Liu Z, et al. Clinical course and risk factors for mortality of adult inpatients with COVID-19 in Wuhan, China: a retrospective cohort study. Lancet [Internet]. 2020;395(10229):1054-62.

7. Malas MB, Naazie IN, Elsayed N, Mathlouthi A, Marmor R, Clary B. Thromboembolism risk of COVID-19 is high and associated with a higher risk of mortality: A systematic review 
and meta-analysis. EClinicalMedicine. 2020 Dec;29:100639.

8. Kapoor S, Chand S, Dieiev V, Fazzari M, Tanner T, Lewandowski DC, et al. Thromboembolic Events and Role of Point of Care Ultrasound in Hospitalized Covid-19 Patients Needing Intensive Care Unit Admission. J Intensive Care Med. 2020 Oct;885066620964392.

9. Wichmann D, Sperhake J-PP, Lütgehetmann $M$, Steurer S, Edler C, Heinemann A, et al. Autopsy Findings and Venous Thromboembolism in Patients With COVID-19: A Prospective Cohort Study. Ann Intern Med. 2020 Aug;173(4):268-77.

10. Zhang L, Feng $X$, Zhang $D$, Jiang $C$, Mei $H$, Wang J, et al. Deep Vein Thrombosis in Hospitalized Patients with COVID-19 in Wuhan, China: Prevalence, Risk Factors, and Outcome. Circulation. 2020 Jul;142(2):11428.

11. Chang $H$, Rockman CB, Jacobowitz GR, Speranza G, Johnson WS, Horowitz JM, et al. Deep vein thrombosis in hospitalized patients with coronavirus disease 2019. J Vasc Surg Venous Lymphat Disord [Internet]. 2020 Oct;

12. Görlinger K, Dirkmann D, Gandhi A, Simioni P. COVID-19-Associated Coagulopathy and Inflammatory Response: What Do We Know Already and What Are the Knowledge Gaps? Anesth Analg [Internet]. 2020 Nov [cited 2021 Jan 19];131(5):1324-33.

13. Wang $Z$, Yang $Y$, Liang $X$, Gao B, Liu M, Li W, et al. COVID-19 Associated Ischemic Stroke and Hemorrhagic Stroke: Incidence, Potential Pathological Mechanism, and Management [Internet]. Vol. 11, Frontiers in Neurology. Frontiers Media S.A.; 2020 [cited 2021 Feb 3]. p. 571996.
14. Spence JD, De Freitas GR, Creed Pettigrew $L$, Ay $\mathrm{H}$, Liebeskind DS, Kase CS, et al. Mechanisms of Stroke in COVID-19. Cerebrovasc Dis [Internet]. 2020 [cited 2021 Feb 4];49:451-8.

15. Akhter N, Ahmad S, Alzahrani FA, Dar SA, Wahid M, Haque S, et al. Impact of COVID-19 on the cerebrovascular system and the prevention of RBC lysis [Internet]. European Review for Medical and Pharmacological Sciences Verduci Editore s.r.l; 2020 p. 1026778.

16. Yamakawa $M$, Kuno $T$, Mikami $T$, Takagi $H$, Gronseth G. Clinical Characteristics of Stroke with COVID-19: A Systematic Review and Meta-Analysis. J Stroke Cerebrovasc Dis [Internet]. 2020 [cited 2021 Feb 5];29(12).

17. Lippi G, Plebani M. Laboratory abnormalities in patients with COVID-2019 infection. Clin Chem Lab Med. 2020;58(7):1131-4.

18. Klok FA, Kruip MJHAHA, van der Meer NJMM, Arbous MS, Gommers D, Kant KM, et al. Confirmation of the high cumulative incidence of thrombotic complications in critically ill ICU patients with COVID-19: An updated analysis. Thromb Res [Internet]. 2020 Jul 1 [cited 2021 Jan 20];191:148-50.

19. Rapkiewicz A V., Mai X, Carsons SE, Pittaluga S, Kleiner DE, Berger JS, et al. Megakaryocytes and platelet-fibrin thrombi characterize multi-organ thrombosis at autopsy in COVID-19: A case series. EClinicalMedicine [Internet]. 2020 Jul 1 [cited 2021 Jan 20];24.

20. Avruscio G, Camporese G, Campello E, Bernardi E, Persona P, Passarella C, et al. COVID-19 and Venous Thromboembolism in Intensive Care or Medical Ward. Clin Transl Sci [Internet]. 2020 Nov 1 [cited 2021 Jan 20];13(6):1108-14. 